\title{
Młode pokolenie wobec pracy, konsumpcji oraz sukcesu
}

DOl: 10.19195/2083-7763.9.2

\section{Wstęp}

Zagadnienia dotyczące młodzieży, młodego pokolenia czy młodych ludzi stanowią przedmiot zainteresowań zarówno nauk społecznych, jak i ekonomicznych, w ramach których formułuje się różne sposoby ich przedstawiania i akcentuje różne cechy charakterystyczne. Zazwyczaj ujęcia te zawierały duży ładunek emocjonalny. Młodzież stanowiła z jednej strony bezcenny kapitał społeczny, a z drugiej nadzieję na „lepszą przyszłość”. Niniejsze opracowanie jest analizą wypowiedzi starszej zbiorowości funkcjonującej w ramach młodego pokolenia przedsiębiorców aktywnych na rynku. Celem jest próba przedstawienia młodego pokolenia w obu najistotniejszych rolach na rynku — zarówno konsumenta, jak i przedsiębiorcy. Warto podkreślić, że ukazanie ich jednocześnie w obu rolach nie byłoby możliwe lub byłoby utrudnione w zbiorowościach młodszych wiekowo, jak uczniowie lub studenci, którzy znacznie rzadziej prowadzą działalność gospodarczą niż osoby po 24. roku życia (do 34 lat). Zarabiając w ramach działalności, przedsiębiorcy jednocześnie mają środki do przeznaczenia na konsumpcję, dlatego ich wybory były interesującym zagadnienieniem. Dodatkowo można przyjąć, że ich poglądy na temat prawa oparte są na własnych doświadczeniach zawodowych. Przeprowadzone analizy jakościowe indywidualnych wywiadów pogłębionych nie uprawniają do wyciągania wniosków na temat całego młodego pokolenia, mogą jedynie wskazywać pewne tendencje w opiniach i zachowaniach młodych osób, a także wskazywać dalszy kierunek badań. Warto podkreślić, że w zbiorowości młodych osoby będące w przedziale wiekowym 24-34 lata są stosunkowo rzadko badane $\mathrm{w}$ przeciwieństwie do młodszych przedstawicieli tego pokolenia (uczniów, studentów). 


\section{Młode pokolenie w badaniach nad społeczeństwem konsumpcyjnym}

Pokolenia to grupy społeczne, które oprócz metryki urodzenia łączą wspólne przeżycia i doświadczenia ${ }^{1}$. Pokolenie zasadniczo można zdefiniować jako zbiorowość ludzi będących w podobnym wieku lub jako ogół osób ukształtowanych przez zbliżone lub te same przeżycia, doświadczenia itp., a także jako okres równy długości życia ludzi urodzonych w podobnym czasie ${ }^{2}$. Pokolenie jest kategorią, która zarówno w myśleniu potocznym, jak i badaniach naukowych pełni funkcję porząadkującą coraz bardziej złożoną i wielowymiarową problematykę młodzieży. To „wspólny mianownik”, umożliwiający chronologiczne, merytoryczne, a często także ideologiczne kategoryzowanie grup osób w podobnym wieku ${ }^{3}$. Kategoria pokolenia daje możliwość połączenia indywidualnej, instytucjonalnej i społecznej perspektywy badawczej ${ }^{4}$. Pokoleniu, będącemu zarówno „intuicyjną miarą czasu historycznego" 5 , jak i kategorią filozoficzną oraz socjologiczną, brak konceptualnej precyzji. K. Wyka opisał trzy etapy naukowej refleksji nad pokoleniem: pozytywistyczny, humanistyczny i socjologiczny ${ }^{6}$. Celem pierwszego była zgodna z imperatywem ciągłego postępu systematyzacja następujących po sobie praw historycznego rozwoju na podstawie biologicznego rytmu życia ludzkiego. Stanowisko to oparto na założeniu, że możliwe i konieczne jest, „by wychodząc bezpośrednio ze sfery biologicznej, zrozumieć formalne przemiany prądów duchowych i społecznych"7. Zdaniem reprezentanta nurtu humanistycznego W. Dilheya - „równoczesność przeżycia” i funkcjonowania w podobnych warunkach społecznopolitycznych nie powinno być interpretowane jako fakt chronologiczny, lecz jako występowanie takich samych, lecz różnie przez ludzi interpretowanych, determinant historycznych. Socjologiczną analizę zapoczątkował K. Manheim, który ukazał związek między funkcjonowaniem w ramach jednej grupy wiekowej, powstawaniem kolektywnej świadomości (tożsamości zbiorowej) a przemianami struktury społecznej ${ }^{8}$.

Można zatem założyć, że obecnie pojęcie to jest najczęściej używane w dwóch podstawowych kategoriach znaczeniowych. Pierwsza z nich to podejście społecz-

${ }^{1}$ M. Andrejczuk, Prekariat a „pokolenie y" - zjawisko prekaryjności młodych pracowników, „Kultura i Rozwój” 2017, nr 2 (3), s. 51-67.

${ }^{2}$ J. Wardzała,Zmiany w postrzeganiu roli młodzieżywe wspótczesnym społeczeństwie, [w:] Konsumpcja jako forma komunikacji społecznej. Nowe paradygmaty i konteksty badawcze, red. W. Patrzałek, J. Wardzała, „Prace Naukowe Uniwersytetu Ekonomicznego we Wrocławiu” 2015, nr 414.

${ }^{3}$ B. Fatyga, Dzicy z naszej ulicy. Antropologia kultury młodzieżowej, Warszawa 2005.

${ }^{4}$ D. Hildebrandt-Wypych, Pokolenia młodzieży - próba konceptualizacji, „Przegląd Pedagogiczny” 2009, nr 2, s. 105-124.

${ }^{5}$ Ibidem, s. 114.

${ }^{6}$ Ibidem, s. 112.

${ }^{7}$ K. Mannheim, Das Problem der Generationen, [w:] Jugend in der Modernen Gesellschaft, red. L. von Friedenburg, Köln-Berlin 1966, s. 23-48.

8 D. Hildebrandt-Wypych, op. cit., s. 120. 
no-kulturowe, w którym pokolenie traktowane jest jako grupa osób urodzonych mniej więcej w tym samym czasie, mających te same doświadczenia historyczne, wykazujących na podstawie podobnych doświadczeń pewne wspólne cechy w sposobie życia i przyjmowanej ideologii, co odróżnia ich od generacji wcześniejszych i późniejszych ${ }^{9}$. W ujęciu biologicznym natomiast akcentuje się poszczególne etapy życia człowieka oraz procesy starzenia się jednostek i grup społecznych, a także związaną z tymi procesami wymianę pokoleń. Procesy biologiczne są tu traktowane jako obiektywna podstawa różnic społecznych, psychologicznych i kulturowych ${ }^{10}$. Badacze społeczeństwa konsumpcyjnego oraz kapitału społecznego stawiają niekiedy hipotezę o wzajemnym powiązaniu tych zjawisk. Odwołują się przy tym do obserwacji współczesnych przemian rzeczywistości społecznej. Z reguły stawiają kapitał społeczny w opozycji do konsumpcjonizmu, który uznaje się za jedną z kluczowych przyczyn jego erozji ${ }^{11}$. M. Herbst stwierdza, że samo określenie „społeczny” wynika $z$ tego, że istnieje on w relacjach między ludźmi i jako skutek interakcji, albowiem dzięki nim uzyskuje dostęp do zasobów (kapitału społecznego, ekonomicznego, kulturowego itp.) wszystkich członków własnej sieci powiązań ${ }^{12}$. Relacje pomiędzy sieciami społecznymi a wymogami życia w społeczeństwie konsumpcyjnym opisuje między innymi P.C. Whybrow. Wskazuje, że członkowie społeczeństwa dobrobytu nastawieni są na sukces i nagradzani za indywidualne osiągnięcia, a nie za tworzenie związków z innymi. Według niego obowiązuje następujący imperatyw kulturowy: „należy się starać, aby zwiększyć swój finansowy sukces, więc zmniejszamy czas na sen, inwestycje w rodzinę i życie społeczne"13. Autor pisze wręcz o „szale materialnego pożądania”, z powodu którego „rozmontowane zostały rodzina, rynek i społeczności” ${ }^{14}$. Społeczeństwo dobrobytu stoi przed wyborem między inwestycją w więzi i zobowiązania $\mathrm{z}$ innymi (rodzina, związki intymne, przyszłe pokolenia itp.) a inwestycją bezpośrednio $\mathrm{w}$ siebie i świat zewnętrzny.

F. Bylok pisze, że czynniki demograficzne są ważną determinantą zachowań konsumpcyjnych. Wskazuje, że do najważniejszych zaliczamy wiek, który jest związany z różnymi potrzebami i sposobami ich zaspokajania, co warunkuje kierunek wydatków konsumpcyjnych, styl konsumpcji i zakres posiadanych dóbr konsumpcyjnych. Proponuje również między innymi podział na dzieci,

9 Ibidem.

${ }^{10}$ D. Hildebrandt-Wypych, op. cit., s. 113.

${ }^{11}$ J. Wardzała, op. cit., s. 252.

12 M. Herbst, Wprowadzenie, o czym jest ta ksiązka, [w:] Kapitał ludzki i kapitał społeczny a rozwój regionów, red. M. Herbst, Warszawa 2007, s. 124.

${ }^{13}$ M. Marciniak, Orientacje konsumpcyjne - bariera w rozwoju kapitału społecznego młodzieży akademickiej? Doniesienie z badań, „Studia Edukacyjne” 2012, nr 22, s. 227-256.

${ }^{14}$ Ibidem, s. 238. 
nastolatków i dorastających, dorosłych i osoby starsze ${ }^{15}$. W innych opracowaniach wskazuje się, że okres młodości obejmuje lata od 18. do 25.-30. roku życia. Autorzy raportu „Młodzi 2011” wskazują dwie kategorie wiekowe młodych: 1524 lata oraz 25-34 lata ${ }^{16}$. Według R.J. Havighursta analizując zadania rozwojowe, możemy wyróżnić między innymi te związane $\mathrm{z}$ wyborem ścieżki edukacyjno-zawodowej, osiąganiem bezpieczeństwa i niezależności ekonomicznej, przygotowaniem się do życia rodzinnego, startem w nowych rolach: rodzinnych i zawodowych, nabyciem zbioru wartości oraz systemu etycznego jako przewodnika zachowania ${ }^{17}$.

W literaturze oraz dyskursie na temat rynku pracy i przemian społecznych często pojawiają się pojęcia „pokolenie X, Y” oraz „pokolenie Z”. R. Waśko pisze, że niektórzy badacze zastanawiają się nad sensem tworzenia kategorii społecznej tego rodzaju, gdyż termin „pokolenie” w tym przypadku można uznać za swego rodzaju nadużycie, a jego wprowadzenie może zniekształcić prawdziwy obraz społeczeństwa. Według niektórych autorów jest to sztuczne tworzenie ram, które są jedynie wytworem teoretyków. Z drugiej strony w takiej kategoryzacji można dopatrywać ułatwienia zrozumienia potrzeb pracowników i pracodawców ${ }^{18}$. Według W. Września na poczucie przynależności pokoleniowej składa się poczucie wspólnoty doświadczeń, wyznaczającej ścieżki kariery zawodowej, poczucie wspólnoty interesów, norm, wartości i wzorów zachowań, przejawiające się w realizowaniu stylu życia, oraz poczucie solidarności ${ }^{19}$.

\section{Praca i sukces w opiniach młodych przedsiębiorców}

Praca może być analizowana jako jeden z ważnych wymiarów życia ludzkiego; tworzy wartość, którą można badać również z perspektywy jej miejsca w życiu człowieka. Można ją rozumieć w wymiarze instrumentalnym i autotelicznym ${ }^{20}$. Postawa instrumentalna to traktowanie pracy jako środka do zaspokajania potrzeb. W tym przypadku dużą rolę odgrywa wynagrodzenie jako ekwiwalent nakładu energii i czasu danej osoby. Praca traktowana w sposób autoteliczny, jako wartość sama w sobie, stanowi element samorozwoju ${ }^{21}$. U. Swadźba wskazuje,

${ }^{15}$ F. Bylok, Kompetencje konsumenckie pokolenia Y w Polsce, [w:] Praca - konsumpcja - przedsiębiorczość. Świadomość ekonomiczna młodego pokolenia, red. U. Swadźba, M. Żak, R. Cekiera, Katowice 2017, s. 313.

${ }^{16}$ K. Szafraniec, Młodzi 2011, Warszawa 2011.

17 A. Wawrzonek, Młodzi dorośli na rynku pracy, „Studia Edukacyjne” 2014, nr 33, s. 305-320.

${ }^{18} \mathrm{R}$. Waśko, Wybrane aspekty różnicujące pokolenie X,Y i Z w kontekście użytkowania nowych technik i Internetu, [w:] Z. Rykiel, J. Kinal, Socjologia codzienności jako niebanalności, Rzeszów 2016.

${ }^{19}$ W. Wrzesień, Czy pokoleniowość nam się nie przydarzy? Kilka uwag o współczesnej polskiej młodzieży, „Nauka” 3, 2007.

${ }^{20}$ W. Jacher, Człowiek i praca: alfabet wiedzy o pracy ludzkiej, Opole 1979, s. 67.

${ }^{21}$ B. Sterniczuk, H. Sterniczuk, Postawy wobec pracy, Warszawa 1979. 
że praca zawodowa determinuje życiową aktywność znacznej części populacji; dzięki pracy zawodowej jednostki znajdują miejsce w społeczeństwie ${ }^{22}$.

Wywiady pogłębione, które tworzyły podstawę empiryczną niniejszego opracowania, zostały przeprowadzone w 2018 roku na 50 liderach drobnych przedsiębiorstw, współpracujących z firmami mającymi kapitał zagraniczny ${ }^{23}$. Wśród badanych znalazło się 12 kobiet i 38 mężczyzn, najmłodszy respondent miał 24 lata, a najstarszy - 34 lata.

Były to głównie osoby z wyższym wykształceniem (często także podyplomowym), na 50 osób jedynie 12 miało średnie wykształcenie, nie było osób z wykształceniem podstawowym. Jak wskazuje się w literaturze, zdobycie wyższego wykształcenia nie jest czynnikiem zmniejszającym różnice w aktywności przedsiębiorczej między kobietami a mężczyznami. Zdecydowanie wyższy odsetek kobiet mających dyplom uniwersytecki podejmuje taką aktywność, jednak proporcja przedsiębiorczych mężczyzn z wyższym wykształceniem również wrasta ${ }^{24}$.

Zawody wyuczone badanych osób to bardzo szeroki wachlarz specjalności - od mechanika samochodowego, przez menedżera turystyki, aż po prawnika. Osoby te często przekwalifikowywały się w trakcie kariery zawodowej. Dochód na osobę w rodzinie połowa respondentów określiła w wyższych pułapach, czyli więcej niż 4000 na osobę, dziesięciu respondentów wskazało, że jest to kwota powyżej $6000 \mathrm{zł}$ na osobę.

W pytaniu o genezę firmy przedsiębiorcy wskazywali, że były to głównie nowo założone przedsiębiorstwa, $\mathrm{w}$ jednym przypadku było to przedsiębiorstwo powstałe w wyniku przekształcenia sektora prywatnego. W 16 przypadkach przedsiębiorcy odeszli z firm, które nie dawały im odpowiednich możliwości.

Pracowałam w wydawnictwie, w którym zajmowałam stanowisko księgowej i w pewnym momencie tej pracy uświadomiłam sobie, że o wiele korzystniej wyszłoby to dla mnie finansowo, gdybym otworzyła własne biuro rachunkowe i prowadziła księgowość innych przedsiębiorstw. (Kobieta, 28 1., biuro rachunkowe)

Kiedy skończyłem pracę w korporacji, dokładnie mówiąc w banku, postanowiłem założyć własną działalność. Zawsze lubiłem dobre obuwie, ale nigdy nie mogłem doświadczyć kupna takiego, jakiego konkretnie chciałem, w przystępnej cenie, zrobionego z dobrej jakości materiałów. Dlatego postanowiłem założyć firmę, która takie buty produkuje, które można zaprojektować dokładnie takie, jakie się chce, z takiego tworzywa, jakie się podoba. Zawsze chciałem być dla

${ }^{22}$ U. Swadźba, Work as a value in the minds of young generations, [w:] Praca - konsumpcja przedsiębiorczość. Świadomość ekonomiczna młodego pokolenia, red. U. Swadźba, M. Żak, R. Cekiera, Katowice 2017.

23 Badania „Pokolenie X i Pokolenie Y jako przedsiębiorcy i konsumenci” pod kierunkiem Joanny Wardzały i Aleksandry Perchli-Włosik realizowane w Instytucie Socjologii Uniwersytetu Wrocławskiego w 2018 roku.

${ }^{24}$ M. Jelonek, K. Kasparek, M. Magierowski, Młodzi na rynku pracy - pracownicy, przedsiębiorcy, bezrobotni. Na podstawie analizy kierunków kształcenia zrealizowanej w 2014 roku w ramach V edycji projektu Bilans Kapitału Ludzkiego. Edukacja a rynek pracy, t. 4, Warszawa 2015. 
siebie szefem i robić to, co sprawia mi satysfakcję i dobre wynagrodzenie. (Mężczyzna, 34 1., salon obuwia)

W dziesięciu przypadkach były to firmy rodzinne - prowadzili je ojcowie, a potem synowie.

Jest to firma rodzinna, a stanowisko szefa przekazywane jest z pokolenia na pokolenie. Mój ojciec założył tę firmę, ja odziedziczyłem ją po nim, moim następcą będzie mój syn. (Mężczyzna 32 l., firma transportowa)

W trzech przypadkach przyjaciele/znajomi założyli firmy po zakończeniu studiów. Powodami rezygnacji przedsiębiorców z poprzednich miejsc pracy były: zbyt niska płaca, upadłość firmy, niechęć do korporacyjnego stylu życia, brak możliwości rozwoju, potrzeba pójścia „na swoje” oraz chęć zdobycia odpowiedniego doświadczenia.

Wielkość firmy określano liczbą zatrudnionych pracowników. Czasem przedsiębiorcy wskazywali roczne obroty. Ich firmy to głównie małe, usługowe przedsiębiorstwa, w największym zatrudnionych było 70 osób, w najmniejszym -14 .

W jaki sposób przedsiębiorcy postrzegają pracę? Respondenci wskazywali wartości, które według nich są związane z pracą. Jedną z najczęściej przywoływanych była uczciwość, wskazało ją aż 30 badanych.

Jedną z najważniejszych rzeczy jest uczciwość względem swoich klientów, ale i utrzymanie rentowności prowadzonej przez siebie działalności i uczciwość względem swoich podwykonawców i dostawców, konsekwencja, systematyczność. (Mężczyzna, 30 1., firma budowlana)

Wartości uznawane za ważne dla aktywności zawodowej znalazły potwierdzenie w charakterystyce dobrego pracodawcy.

Myślę, że taką wartością jest uczciwość. Uczciwość w prowadzeniu biznesu, w stosunku do ich współpracowników, pracowników i kontrahentów. To jest taka cecha bardzo potrzebna. Tak to widzę. (Mężczyzna, 32 l., firma budowlana)

Jako wartości ważne i związane z pracą oprócz uczciwości wskazywano pracowitość, zrozumienie potrzeb pracownika oraz odpowiedzialność. Co ciekawe, chęć zysku albo nawet utrzymania się na rynku podkreślane były dość rzadko, raczej jako efekt dobrej współpracy zespołu.

Ja osobiście cenię sobie przede wszystkim dobrą atmosferę w pracy, ślepe dążenie do zarabiania pieniędzy kłóci się z moimi poglądami. Wychodzę z założenia, że jeżeli pracownicy będą się czuli dobrze w tym, co robią, to przełoży się na efektywność naszej zbiorowej pracy, także no, staram się robić wszystko, aby tak było. Wraz z moim zespołem tworzymy pewnego rodzaju rodzinę, utrzymujemy przyjazne stosunki także poza pracą. (Mężczyzna, 33 l., firma logistyczna)

Wraz z przywołaniem uczciwości oraz dobrej atmosfery w miejscu pracy bardzo często wskazywano jakość pracy skutkującą dobrymi produktami i satysfakcją klientów. 
Myślę, że przedsiębiorca powinien kierować się determinacją w dążeniu do celu, no oczywiście nie kosztem swoich pracowników, powinien być zaangażowany w to, co robi, oraz powinno mu też zależeć na satysfakcji swoich klientów/gości. (Kobieta, 32 l., firma consultingowa)

Po drugie, jakość produktu, to jest jedna z najważniejszych spraw. Jeśli twój produkt ma czym się wyróżnić na rynku, to już jest połowa sukcesu. Do jakości coraz mniej przedsiębiorców przywiązuje uwagę. (Mężczyzna, 31 l., sklep ze sprzętem specjalistycznym)

Trudno nie odnieść wrażenia, że młodzi polscy przedsiębiorcy nie boją się już otwartego mówienia o dążeniu do sukcesu w obawie przed niechęcią innych i podejrzeniem, że nieuczciwie zarabiają pieniądze. Sukces przedsiębiorcy nie jest też określany jako wyzysk podwładnych, lecz wspólna, ciężka praca. Coraz częściej budzi on podziw i chęć naśladowania. Interesujące jest to, że praca „na swoim” nie była określana przez przedsiębiorców jako źródło utrzymania, czynność, którą muszą wykonywać, ale jako coś, co daje satysfakcję i spełnienie zawodowe wynikające z tworzenia czegoś (produktu, usługi) we współpracy z innymi osobami.

Jestem w stanie utrzymać się z tego, co lubię robić i chcę robić, więc to jest chyba to, co uważam za sukces zawodowy. (Mężczyzna, 32 1., sklep optyczny)

Potwierdzają to przywołane analizy teoretyczne dotyczące zmiany tradycyjnego etosu pracy w Polsce w latach 90.

Wskazując cechy pracowników, większość respondentów wyróżniła uczciwość. Podkreślano także lojalność i pracowitość.

Duża mobilność, chęci do pracy, sumienność, uczciwość i przede wszystkim muszą być odpowiedzialni. (Mężczyzna, 29 l., firma budowlana)

Jako cenne wskazywano też zaangażowanie w pracę i wiarę w to, czym zajmuje się firma.

Pracownik powinien być na pewno rzetelny i sumiennie wypełniać swoje obowiązki. Dobrze też, jak jest w pewien sposób przywiązany do firmy. Wydaje mi się, że wtedy przykłada się do pracy bardziej niż taki, któremu działalność firmy jest zupełnie obojętna. (Kobieta, 28 l., firma rachunkowa)

Często podkreślano drobne - jak się wydaje — sprawy związane z nawykami pracowników, które mogą mieć duże znaczenie w organizacji pracy.

Najważniejsze chyba to bycie punktualnym, ja przestrzegam tej zasady i również wymagam tego od innych, nie cierpię wprost, jak ktoś się spóźnia. (Mężczyzna, 32 1., sklep ze sprzętem specjalistycznym)

Co ciekawe, przedsiębiorcy mimo pełnej otwartości na dobrą atmosferę w pracy rzadko wskazywali konieczność samodzielnego myślenia lub kreatywność ze strony pracownika. Było to natomiast podkreślane jako niezbędne w przypadku cech przedsiębiorcy.

Kolejne pytania dotyczyły pojęcia sukcesu w rozumieniu przedsiębiorcy. Biznesmeni podkreślali konieczność znalezienia niszy rynkowej, w której nic 
jeszcze nie jest produkowane ani nie są świadczone usługi. Jeśli będzie zapotrzebowanie na nowy pomysł, sukces będzie bardzo prawdopodobny.

Najlepiej znaleźć niszową dziedzinę, której jeszcze nie ma, a poprzez badanie rynku dowiemy się, czy byłby na to popyt, zainteresowanie, czy w ogóle ludzie chcą i potrzebują naszego przedsiębiorstwa i jeśli te czynniki się zgrają, to wydaje mi się, że jest duża możliwość sukcesu. (Kobieta, 32 l., firma rachunkowa)

Prawie każdy z przedsiębiorców przywoływał konieczność posiadania determinacji w dążeniu do celu, niepoddawanie się i ciężką pracę.

Sukces najczęściej kojarzył się respondentom z finansami i stworzeniem nowych form produktu lub usługi. Padały stwierdzenia odnoszące się do stabilizacji biznesu, to znaczy za sukces uważano wieloletnie funkcjonowanie firmy na rynku.

Jestem jeszcze w trakcie osiągania, dążę do tego sukcesu. Natomiast utrzymanie firmy przez dziesięć lat jest jakimś sukcesem. (Mężczyzna, 28 l., sklep ze sprzętem specjalistycznym)

Wielu badanych za sukces uznawało rozwój firmy w czasie.

Założyłem firmę, maleńką, dwuosobową na początku, tak. A potem ta firma się rozrosła. Doszliśmy do takiego poziomu, na jakim teraz się znajdujemy. Jesteśmy już firmą liczącą się na rynku w naszej branży, to jest największy sukces. (Mężczyzna, 28 l., sklep logistyczny)

Doświadczeni biznesmeni wskazywali również brak cierpliwości ze strony początkujących przedsiębiorców. Podkreślali, że brakuje im pozytywnego myślenia.

A wszystkim tym bolączkom winne państwo, politycy, ZUS, gospodarka i wszystko dookoła. Nie widzę w nich cierpliwości i uporu w dążeniu do celu. A może nawet oni nie widzą żadnego celu. Właśnie taka postawa to wręcz „antysposób” na sukces zawodowy. (Mężczyzna, 34 1., sklep obuwniczy)

Przedsiębiorców poproszonych o ocenę, czy sami odnieśli w życiu sukces zawodowy, można podzielić na dwie kategorie - tych, którzy przyznali, że odnieśli w życiu sukces zawodowy, i tych, którzy podkreślili, że dążą do tego celu. Praktycznie wszyscy badani wskazywali materialny wymiar sukcesu. Nie było osób, które negatywnie wypowiadały się o sukcesie.

Przedsiębiorców, którzy - we własnym mniemaniu — odnieśli sukces, było zdecydowanie mniej, ale bez problemu i z dumą opowiadali o swoich osiągnięciach:

Uważam, że odniosłem duży sukces. Wziąwszy pod uwagę, od czego zaczynałem, z jakiego środowiska się wywodzę, w mojej ocenie jest to duży sukces. Natomiast daleko mi do jeszcze do listy stu najbogatszych Polaków, więc tutaj, patrząc z tej strony, ten sukces nie jest aż taki duży. Ja jestem zadowolony z tego, co osiągnąłem. (Mężczyzna, 25 l., sklep ze sprzętem specjalistycznym)

Czuję się osobą spełnioną, która osiągnęła swój cel. Człowiek zawsze chciałby więcej, jednak na tyle, na ile warunki w firmie pozwalają, na tyle czuję się spełniony. (Mężczyzna, 34 l., firma logistyczna) 
Większość respondentów ostrożnie podchodziła do próby samooceny podejmowanych działań, ale były to głównie pozytywne prognozy na zawodową przyszłość.

\section{Oczekiwania młodego pokolenia wobec obowiązującego prawa i gospodarki}

Zapytana o sytuację polskiej gospodarki, znaczna większość respondentów wskazywała, że Polska ekonomicznie nie do końca rozwija się w dobrym kierunku. Biznesmeni, przyrównując sytuację Polski do sytuacji gospodarki innych krajów, twierdzili, że nie jest najlepiej.

Kiedy będą mniejsze podatki. (Mężczyzna, 25 1., sklep ze sprzętem specjalistycznym)

Są gorsze, coraz więcej „,papierkologii”. (Mężczyzna, 28 1., sklep obuwniczy)

Trudno jednoznacznie wydać jakąś kategoryczną ocenę. Jeżeli spojrzy się na to, jak następuje konsumpcja i jaki jest poziom życia ludzi, to on oczywiście się zwiększa z roku na rok, także z tej strony można mówić o pewnych plusach. Mamy też pewien plus dla gospodarki, który wcale nie jest olbrzymim plusem dla pracodawcy — jest to pomniejszające się bezrobocie. (Kobieta, 32 l., firma konsultingowa)

Prawie wszyscy badani wskazywali, że warunki prowadzenia działalności gospodarczej nie są najlepsze. A nawet często dodawano, że są trudne.

Mam w sumie do zarzucenia polskiej gospodarce zbyt duży formalizm oraz zbyt duże wymagania prawne dla podmiotów, które chcą zająć się pracą wyspecjalizowaną. (Mężczyzna, 32 1., firma detektywistyczna)

Jedynie 8 osób zauważyło, że nie są potrzebne zmiany, gospodarka jest na właściwym poziomie rozwoju, ale były to osoby, które założyły firmę w ciągu ostatniego roku. Ta prawidłowość była zgodna $\mathrm{z}$ wypowiedziami innych osób, które wskazywały, że według nich korzystne rozwiązania prawne i gospodarcze wprowadzane są tylko dla nowo powstałych przedsiębiorstw, te zaś, które funkcjonują na rynku dłuższy czas, mają trudniej.

Większość przedsiębiorców, mimo niezbyt pozytywnych opinii o sytuacji gospodarczej w kraju, była zadowolona z sytuacji własnej firmy.

Jesteśmy zadowoleni w pełni, nie było nigdy sytuacji, żeby z czegoś się nie wywiązywali, zawsze wszystko jest sprawnie i na czas, także... no nie wiem, może to kwestia szczęścia, a może po prostu odpowiedzialnego doboru współpracowników. (Kobieta, 28 1., firma konsultingowa)

Mimo zadowalającego w opinii młodych przedsiębiorców stanu rzeczy każdy $\mathrm{z}$ nich wskazywał, że konieczne są w Polsce zmiany w zakresie gospodarki 
$\mathrm{w}$ różnym zakresie, niekiedy $\mathrm{w}$ zakresie regulacji prawnych, niekiedy — polityki rządu w sprawach przedsiębiorstw.

Młodzi przedsiębiorcy na dzień dzisiejszy mają bardzo utrudniony start. Poza działalnością w zakresie IT, wszystkie firmy handlowe i produkcyjno-handlowe mają dość duży problem na starcie. (Mężczyzna, 28 1., firma kateringowa)

Przedsiębiorcy oceniali polskie regulacje prawne jako skomplikowane zarówno w przeszłości, jak i obecnie, niezależnie od ugrupowania politycznego sprawującego władzę.

Jeśli chodzi o regulacje prawne, to one wciąż są tak samo zagmatwane, jak były. (Kobieta, 30 l., firma konsultingowa)

Nie jest to w takim stopniu, że młody przedsiębiorca czuje, że ma duże wsparcie od państwa. (Kobieta, 28 1., firma konsultingowa)

Przepisy często były oceniane $\mathrm{w}$ dwóch aspektach. Jeden z można określić jako aspekt jakościowy, a drugi jako ilościowy. Odnośnie do aspektu jakościowego młodzi przedsiębiorcy pozytywnie oceniali regulacje, wskazując, że przepisy z lat 90 . bardzo często pozwalały na wiele nadużyć i działalność przestępczą. W aspekcie ilościowym podkreślano, że przepisów jest nieporównywalnie więcej. Wskazywano, że dzisiejszy przedsiębiorca musi spełniać wiele wymogów, których dawniej nie trzeba było spełniać. W przeszłości łatwiej prowadziło się działalność gospodarczą.

Zrozumiałe oczywiście jest to, że regulacje prawne są konieczne, żeby nie było nadużyć, ale jednakże takie nagromadzenie przepisów jest niekorzystne, bo hamujące. (Mężczyzna, 31 1., sklep ze sprzętem specjalistycznym)

Czasami krytykowano aktualne rozwiązania i zmiany:

Więc moim zdaniem akurat takie pseudo udogodnienia tylko robią więcej problemów, ponieważ ci ludzie nie mają realnej wiedzy na ten temat a biorą się za coś, co albo upadnie, albo pociągną za sobą innych, którzy będą próbowali prowadzić tego typu działalność. (Kobieta, 27 l., firma konsultingowa)

W stosunku do tego, kiedy myśmy zakładali działalność, przybyło bardzo dużo regulacji prawnych odnośnie do recyklingu, odnośnie do sprawozdawczości. Dużo więcej statystyk i sprawozdań trzeba składać do urzędu. (Mężczyzna, 33 l., sklep ze sprzętem specjalistycznym)

Wśród respondentów byli też przedsiębiorcy wskazujący pozytywny postęp w obecnych regulacjach, odnosili się w nich do regulacji międzypokoleniowych.

Wtedy, kiedy my ją zakładaliśmy, musieliśmy po różnych urzędach biegać, stawać w kolejkach i załatwialiśmy to prawie tydzień. W tej chwili, nie wiem, czy ludzie nie zdają sobie z tego sprawy, ale firmę załatwia się dużo krócej. Można to zrobić w ciągu godziny. (Mężczyzna, 34 1., sklep obuwniczy)

Za największe utrudnienia w kontynuowaniu działalności zarówno najmłodsi, jak i trochę starsi przedsiębiorcy uznali nadmierne obciążenia podatkowe, zbyt 
dużą konkurencję, a także uciążliwe przepisy prawne. Przy czym osoby do 30 . roku życia częściej wymieniały takie czynniki, jak zbyt duże obciążenia podatkowe oraz niedostateczne doświadczenie. Niezależnie od wieku większość osób prowadzących działalność nie przewidywała większych zmian w zakresie działania firmy. O rozszerzaniu działalności częściej niż starsi przedsiębiorcy myśleli młodzi, wśród przedsiębiorców po 30. roku życia o zamiarach rozszerzenia działalności wspomina zaledwie kilku badanych. Nastroje wśród przedsiębiorców zależą również od branży, w której działają. Wzrost swojej firmy najczęściej prognozowali młodzi przedsiębiorcy z branży usług specjalistycznych oraz transportu.

Katalog czynników utrudniających młodym kobietom-przedsiębiorcom prowadzenie działalności gospodarczej jest szerszy niż w przypadku mężczyzn-przedsiębiorców. Co prawda kobiety, podobnie jak mężczyźni, najczęściej wskazują zbyt duże obciążenia podatkowe, konkurencję oraz uciążliwe przepisy prawne, jednak dla pań nie bez znaczenia pozostaje sytuacja rodzinna, która w przypadku mężczyzn nie stanowi głównej przyczyny ograniczania działalności.

Podsumowując fragmenty wypowiedzi respondentów dotyczące gospodarki oraz przepisów prawnych, można stwierdzić, że są one stabilne, pomimo przeszkód. Niektórzy zauważają trend wzrostu, inni - spadku, ale takie opinie mogą mieć podłoże w politycznych poglądach przedsiębiorców. Większość badanych wskazywała jednak, że jest coraz trudniej, ale to tendencja ogólnoświatowa.

Myślę że nasza gospodarka w stosunku do innych gospodarek trzyma się dość dobrze, natomiast wystrzeliłoby to niewątpliwie do góry, gdyby pewne uwarunkowania prawne zostały złagodzone i to zostałoby uczynione dla pracodawcy. (Mężczyzna, 31 1., sklep ze sprzętem specjalistycznym)

\section{Dominujące wśród młodych ludzi wartości związane z konsumpcją}

We współczesnej gospodarce, zwłaszcza w krajach rozwiniętych o gospodarce rynkowej, aksjomatem wydaje się stwierdzenie wyraźnego wpływu konsumpcji na przebieg i efekty rozwoju społeczeństwa i gospodarki ${ }^{25}$. A. Olejniczuk-Merta pisze, że innowacyjność konsumenta wynika $\mathrm{z}$ własnego obrazu (samoocena, samoakceptacja), a także obrazu otaczającego świata (bezpieczny, podlegający wpływom danej osoby) oraz poczucia miejsca kontroli (wewnątrz samego siebie lub na zewnątrz siebie). Te cechy determinują określone zachowania konsumenta - szczególnie w zakresie podejmowania decyzji, otwartości do zmian sytuacji, w których się znajduje, szybkości reagowania na nie - a nawet wpływają na pełnienie przez niego ról społecznych. Pozytywny obraz samego siebie, samoakceptacja, pozytywny obraz otaczającego świata oraz poczucie samodzielności

${ }^{25}$ A. Olejniczuk-Merta, Od innowacyjności konsumentów do innowacyjnej gospodarki, „Handel Wewnętrzny” 2018, nr 4, s. 253. 
w podejmowaniu decyzji - wraz z samokontrolą własnego zachowania, bez ulegania wpływom innych - sprawiają, że człowiek staje się liderem opinii. Odpowiednio niski poziom wskazanych cech powoduje zaś, że człowiek-konsument jest mniej aktywny, mniej kreatywny, mniej otwarty na innych, wyraża ograniczone zaufanie wobec innych osób, instytucji, przedsiębiorstw. Jego skłonność do innowacji jest $\mathrm{z}$ reguły niska. To pokazuje zarazem, że innowacyjność, która dosyć szeroko jest kojarzona z nowymi produktami, innowacjami technologicznymi, naprawdę jest cechą człowieka, pojęciem społecznym, a nie technologicznym i z tej racji wpływa na konsumpcję dóbr ${ }^{26}$. Jednocześnie jest czynnikiem motywującym konsumentów do aktywizacji społecznej i zawodowej, urealniającej i zwiększającej szanse na rozwój innowacyjności poza konsumpcją, kiedy człowiek realizuje inne role.

H. Klages, badając społeczeństwo zachodnioniemieckie, odkrył, że takie wartości, jak: posłuszeństwo, porządek, uleganie innym i dopasowywanie się do innych straciły na znaczeniu na rzecz wartości związanych z emancypacją od autorytetów, wolnością, kreatywnością, dążeniem do realizacji tych wartości. Możliwości realizacji tych wartości były w konsumpcji, gdzie nie można było realizować indywidualnych celów. Jednostki w coraz mniejszym stopniu kładły nacisk na poszukiwanie i nabywanie nowych produktów ${ }^{27}$. Z drugiej strony jednym z kluczowych komponentów skutecznej kampanii marketingowej w mediach społecznościowych jest budowanie „społecznego autorytetu”. Tworzy się on i rozwija, kiedy jednostka lub organizacja uściśla siebie samą jako eksperta $w$ danej dziedzinie, a przez to staje się w niej wpływowa ${ }^{28}$.

„Przemiany w systemach wartości i norm moralnych związanych z rozwojem bogatych, pluralistycznych społeczeństw $\mathrm{w}$ świecie zachodnim zapoczątkowały jednak przemiany paradygmatu pracy w paradygmat konsumpcji" ${ }^{29}$. Nawiązując do tego cytatu, warto wprowadzić pojęcie prosumpcji. Zachowania prosumenckie to - zgodnie z definicją zaproponowaną przez $\mathrm{Xie}^{30}$ - podejmowane przez konsumenta czynności kreujące wartość. Rezultatem tych działań jest stworzenie produktów będących przedmiotem konsumpcji. Zakres tego pojęcia obejmuje zachowania, do których można zaliczyć samodzielne produkowanie dóbr, następnie konsumowanych, ocenianie i opiniowanie produktów na forach internetowych,

26 Ibidem, s. 256.

27 M. Klages, Wertorientierungen in Wandel, Rückblick, Gegenwartsanalyse, Prognosen, Frankfurt am Main-New York 1985.

28 M. Dorenda-Zaborowicz, Marketing w social media, „Nowe Media” 3, 2012, s. 59-79.

29 F. Bylok, U. Swadźba, D. Walczak-Duraj, Praca i konsumpcja w perspektywie tworzenia ładu aksjonormatywnego, Katowice 2016, s. 137.

30 C. Xie, R. Bagozzi, S. Troye, Trying to prosume: toward a theory of consumers as co-creators of value, „Journal of the Academy of Marketing Science” 2008, nr 36 (1). 
stronach sklepów itp. ${ }^{31} \mathrm{~W}$ związku z tym badani przedsiębiorcy zostali również zapytani o wiedzę i opinie w zakresie konsumpcji, ale ze względu na cechy zawodowe respondentów wzięte pod uwagę zostały także aspekty prawne zagadnienia ${ }^{32}$.

Współczesne społeczeństwo angażuje głównie swoich członków w konsumpcję. Podstawą bytu społeczeństwa konsumpcyjnego jest możliwość dokonywania wyborów. Z. Bauman, porównując tożsamość ponowoczesnego człowieka do dobra konsumpcyjnego, które należy posiąść, a następnie pozwolić mu zniknąć, formułował jednocześnie tezę o przechodzeniu współczesnych społeczeństw od etyki pracy do estetyki konsumpcji ${ }^{33}$. Można zatem stwierdzić, że w społeczeństwach, w których system ekonomiczny jest oparty na logice gospodarki rynkowej, nabywanie nowej tożsamości (grupowej, zawodowej, klasowej) odbywa się poprzez zachowania konsumenckie. Zdaniem R. Sonneta praca, rozumiana w sensie tradycyjnym, stała się przywilejem, nie brakuje osób, które pracują bez przerwy, często będąc uzależnionymi od pracy „zadowolonymi niewolnikami”34. Jednak w przeciwieństwie do społeczeństwa produkcyjnego wywodzą się oni $\mathrm{z}$ elit. Następuje odejście od tradycyjnego etosu pracy, związanego z poczuciem obowiązku, dyscypliną, punktualnością, podporządkowaniem i posłuszeństwem. Zaczynają dominować wartości konsumpcyjno-hedonistyczne oraz indywidualistyczne. Szczególny wpływ na kształtowanie się młodego pokolenia mają internet i nowe technologie, które wykorzystywane są nie tylko w celach rozrywkowych (gry, filmy), lecz także komunikacyjnych i twórczych (np. pisanie blogów, tworzenie grup w mediach społecznościowych).

Na mediach społecznościowych jest możliwość kupowania produktów, nigdy na to nie wchodzę i nie korzystam z tego. Natomiast jeżeli ktoś jest wzrokowcem i po prostu zobaczy i na to kliknie, to już jakby dany sklep ma nowego klienta, bo pewnie coś sobie kupi. (Mężczyzna, 31 1., sklep ze sprzętem specjalistycznym)

Osobiście wolę zakupy tradycyjne, ponieważ wolę wszystko sprawdzić, obejrzeć dokładnie i wypróbować, a nie tylko na obrazku przejrzeć. (Mężczyzna, 28 1., sklep ze sprzętem specjalistycznym)

Uważam, że tradycyjne zakupy, takie w sklepach stacjonarnych, są lepsze, bo możemy zobaczyć, czy coś faktycznie tak wygląda i z jakiego jest materiału i dopasować produkt lub usługę do własnych potrzeb. (Kobieta, 27 l., firma konsultingowa)

Nie kupowałabym raczej przez Facebooka, na przykład ubrań, ale wiem, że jest dużo reklam w mediach społecznościowych, które odsyłają do różnych innych stron. Na przykład znajomi wystawiają też różne rzeczy na Facebooku, które chcą sprzedać lub oddać. Powinny się tym zająć

${ }^{31}$ I. Sowa, Czynniki sprzyjające postawom prosumenckim młodych konsumentów, „Handel Wewnętrzny" 2016, nr 3, s. 306.

32 J. Wardzała, Wiedza i opinie młodych konsumentów w zakresie zakupów w mediach społecznościowych - aspekty prawne i społeczne, „Prace Naukowe Uniwersytetu Ekonomicznego we Wrocławiu" 2017, nr 501, s. 176.

${ }^{33}$ F. Bylok, U. Swadźba, D. Walczak-Duraj, op. cit., s. 137.

${ }^{34}$ Ibidem, s. 139. 
strony internetowe typowo przeznaczone do tego oraz sklepy stacjonarne. (Kobieta, 24 1., firma kateringowa)

Według F. Byloka na kompetencje konsumenckie składają się wiedza teoretyczna i umiejętności praktyczne, pozwalające konsumentowi na sprawną, skuteczną, odpowiadającą oczekiwaniom jakościowym realizację potrzeb niższego i wyższego rzędu przy zachowaniu odpowiedzialności za dokonywanie wyborów i podejmowanie decyzji konsumenckich. Wśród umiejętności konsumenckich wskazano kompetencje informatyczne, które obejmują umiejętne i krytyczne wykorzystanie technologii informacyjno-komunikacyjnych $\mathrm{w}$ procesie zaspokajania potrzeb ${ }^{35}$. $\mathrm{Z}$ badań jednak wynika, że nie zdominowały one strategii zakupowych młodego pokolenia.

Ja nie kupuję przez interent, ale moje znajome na przykład kupują i w sumie to jest coś fajnego, bo można kupić drogą rzecz za małe pieniądze. (Kobieta, 32 1., firma rachunkowa)

Ogólnie przez Facebooka bym nie kupował, bo jednak jest to używane, a ja wolę nowe, bo nie wiadomo, kto i w jakich warunkach to przetrzymywal. A jednak nowe no to wiem, że jest to ze sklepu i po prostu siebie wybiorę i już mam, a tak to po prostu biorę w ciemno przez internet. No i nie wiem, czy nie kupuję kota w worku. (Mężczyzna, 32 1., firma transportowa)

Myślę, że to fajna opcja, ponieważ ktoś z miasta, kto mieszka niedaleko, ma fajną rzecz i chciałabym ją kupić, dlatego nie muszę jechać specjalnie do centrum handlowego, tylko do tej osoby. (Kobieta, 32 1., firma rachunkowa)

$\mathrm{Z}$ wypowiedzi respondentów wynika też, że wpływ mediów społecznościowych na decyzje zakupowe konsumenta objawia się na ogół w momencie, gdy wiedza na temat produktu jest mała lub gdy w grę wchodzą duże sumy pieniędzy do wydania. Można założyć, że im konsument ma większą wiedzę na temat produktu, tym częściej podejmuje samodzielne decyzje, a jeśli takich informacji nie ma, szuka ich $\mathrm{w}$ różnych źródłach, przede wszystkim $\mathrm{w} \operatorname{sieci}^{36}$. Na ujawnienie się prosumpcji, o której była już mowa, wpływa głównie częstotliwość wykorzystywania nowoczesnych technologii. Natomiast postawy prosumenckie nastawione na czerpanie wartości są kształtowane przez podejmowanie aktywności innej niż korzystanie z komputera, na przykład realizację zainteresowań sportowych, artystycznych i prowadzenie życia towarzyskiego. To nie zaangażowanie w nawiązywanie relacji społecznych i towarzyskich decyduje o aktywnej postawie prosumenckiej, lecz korzystanie z zaawansowanych technologii. Problemem, który może być przedmiotem dalszych dociekań, jest pytanie, czy niewielki współudział w tworzeniu wartości jest wynikiem ograniczonego korzystania z technologii IT, czy raczej niewykorzystywanie technologii jest rezultatem zainteresowania innymi aktywnościami.

\footnotetext{
35 Ibidem, s. 314.

36 J. Wardzała, Wiedza..., s. 178.
} 


\section{Podsumowanie}

B. Fatyga pisze, że do postawienia tezy o powstaniu jakiegoś pokolenia potrzeba czasu, który w sytuacji „pokoleniowej akceleracji” może okazać się „wrogiem”, zamykającym usta i oczy na zjawiska dziejące się „tu i teraz”. Wskazuje, że o tym, czy faktycznie doszło do wykreowania pokoleniowej legendy i czy dana "generacja” wytrzymała próbę czasu, można się przekonać dopiero ex post. Chcąc jednak badać współczesne grupy i wspólnoty, obserwować „żywe pokolenia”, „skazani jesteśmy na postępujący brak pewności”; sytuację, w której opis staje się tylko przybliżeniem - jedną z wielu możliwych interpretacji ${ }^{37}$.

Analiza sytuacji młodego pokolenia w Polsce w ostatnich latach pokazuje, że globalizacja rynku i konsumpcji zarówno sprzyja rozwojowi aktywności ludzi młodych, jak i ją ogranicza. Konsumpcja dla młodego pokolenia, także przedsiębiorców, stała się powodem manifestowania uczuć, racjonalizacji miejsca pracy i wyobcowania człowieka $z$ natury. Przestała być postrzegana jako sfera zaspokajania potrzeb egzystencjalnych, stała się obszarem, w którym można bez przeszkód realizować potrzeby związane ze sferą społeczną i psychologiczną. Zatem konsumpcja i podejmowanie aktywności zawodowej to jedne z najważniejszych sfer życia ludzkiego, w których można zrealizować indywidualne cele. Obie stały się w działalności człowieka celem samym w sobie, przekształciły się w wartość.

\section{Bibliografia}

Andrejczuk M., Prekariat a „pokolenie y” - zjawisko prekaryjności młodych, „Kultura i Rozwój 2017", nr 2 (3).

Bauman Z., Etyka ponowoczesna, Warszawa 1996.

Bauman Z., Globalizacja, Warszawa 2000.

Bauman Z., Praca, konsumpcjonizm i nowi ubodzy, Kraków 2006.

Beder S., Consumerism - an historical perspective, „Pacific Ecologist” 2000, nr 9.

Bylok F., Kompetencje konsumenckie pokolenia Y w Polsce, [w:] Praca - konsumpcja - przedsiębiorczość. Świadomość ekonomiczna młodego pokolenia, red. U. Swadźba, M. Żak, R. Cekiera, Katowice 2017.

Bylok F., Wzór sukcesu w społeczeństwie polskim w okresie transformacji społeczno-ustrojowej, „Annales. Etyka w życiu gospodarczym" 2005, nr 8.

Bylok F., Swadźba U., Walczak-Duraj D., Praca i konsumpcja w perspektywie tworzenia ładu aksjonormatywnego, Katowice 2016.

Cronk R., Consumerism and New Capitalism. Art. On the Rebound a Collection of Essays on Art and Culture, New York 1996.

Czarnecka A., Słocińska A., Postawy pokolenia Y wobec pracy na przykładzie studentów pierwszego roku kierunku zarzadzanie. Kompetencje konsumenckie pokolenia Y w Polsce, [w:] Praca - konsumpcja - przedsiębiorczość. Świadomość ekonomiczna młodego pokolenia, red. U. Swadźba, M. Żak, R. Cekiera, Katowice 2017.

${ }^{37}$ B. Fatyga, op. cit., s. 68. 
Dąbrowska A., Bylok F. Janoś-Kresło M., Kiełczowski D., Ozimek I., Kompetencje konsumentów, innowacyjne zachowania, zrównoważona konsumpcja, Warszawa 2015.

Dorenda-Zaborowicz M., Marketing w social media, „Nowe Media” 3, 2012, s. 59-79.

Fatyga B. Dzicy z naszej ulicy. Antropologia kultury młodzieżowej, Warszawa 2005.

Firkowska-Mankiewicz A., Czym jest sukces życiowy dla współczesnego Polaka?, [w:] Elementy nowego ładu, red. H. Domański, A. Rychard, Warszawa 1997.

Haromszeki Ł., Rola przywódców organizacyjnych $w$ kształtowaniu postaw wobec pracy, Wrocław 2016.

Herbst M., Wprowadzenie, o czym jest ta książka, [w:] Kapitał ludzki i kapitał społeczny a rozwój regionów, red. M. Herbst, Warszawa 2007.

Hildebrandt-Wypych D., Pokolenia młodzieży - próba konceptualizacji, „Przegląd Pedagogiczny” 2009, $\mathrm{nr} 2$.

Jacher W., Człowiek i praca, alfabet wiedzy o pracy ludzkiej, Opole 1979.

Jelonek M., Kasparek K., Magierowski M., Młodzi na rynku pracy - pracownicy, przedsiębiorcy, bezrobotni. Na podstawie analizy kierunków kształcenia zrealizowanej w 2014 roku w ramach V edycji projektu Bilans Kapitału Ludzkiego. Edukacja a rynek pracy, t. 4, Warszawa 2015.

Klages M., Wertorientierungen in Wandel, Rückblick, Gegenwartsanalyse, Prognosen, Frankfurt am Main-New York 1985.

Mannheim K., Das Problem der Generationen, [w:] Jugend in der Modernen Gesellschaft, red. L. von Friedenburg, Köln-Berlin 1966.

Marciniak M., Orientacje konsumpcyjne - bariera w rozwoju kapitału społecznego młodzieży akademickiej? Doniesienie z badań, „Studia Edukacyjne” 2012, nr 22.

Olejniczuk-Merta A., Od innowacyjności konsumentów do innowacyjnej gospodarki, „Handel Wewnętrzny" 2018, nr 4.

Ramkin J., The New Capitalism into Commers, „Los Angeles Times” 2000, nr 17/01.

Sonnet R., Korozja charakteru. Osobiste konsekwencje pracy w nowym kapitalizmie, Warszawa 2006.

Sowa I., Czynniki sprzyjające postawom prosumenckim młodych konsumentów, „Handel Wewnętrzny" 2016, nr 3.

Sterniczuk B., Sterniczuk H., Postawy wobec pracy, Warszawa 1979.

Swadźba U., Work as a value in the minds of young generations, [w:] Praca - konsumpcja - przedsiębiorczość. Świadomość ekonomiczna młodego pokolenia, red. U. Swadźba, M. Żak, R. Cekiera, Katowice 2017.

Szafraniec K., Młodzi 2011, Warszawa 2011.

Walczak-Duraj D., Netokratyczna etyka w społeczeństwie, [w:] E-gospodarka, e-społeczeństwo w Europie Środkowej, red. S. Partycki, Lublin 2006.

Walczak-Duraj D., Rola społecznej odpowiedzialności w zarządzaniu reputacja ponadnarodowych korporacji, [w:] Nowa ekonomia a społeczeństwo informacyjne, red. S. Partycki, Lublin 2006.

Walczak-Duraj D., Wzorce i wzory wybranych ról społecznych, „Acta Universitatis Lodziensis, Folia Sociologica” 2001, nr 29.

Walczak-Duraj D., Zróżnicowane podejście do wartości moralnych w gospodarce wolnorynkowej, [w:] Wartości, postawy i więzi moralne w zmieniający się społeczeństwie, red. J. Mariański, L. Smyczek, Lublin 2006.

Wardzała J., Wiedza i opinie młodych konsumentów w zakresie zakupów w mediach społecznościowych: aspekty prawne i społeczne, „Prace Naukowe Uniwersytetu Ekonomicznego we Wrocławiu" 2017, nr 501.

Wardzała J., Zmiany w postrzeganiu roli młodzieży we współczesnym społeczeństwie, [w:] Konsumpcja jako forma komunikacji społecznej. Nowe paradygmaty i konteksty badawcze, red. W. Patrzałek, J. Wardzała, „Prace Naukowe Uniwersytetu Ekonomicznego we Wrocławiu” 2015, nr 414.

Waśko R., Wybrane aspekty różnicujące pokolenie X,Y $\mathrm{i} Z$ w kontekście użytkowania nowych technik i Internetu, [w:] Socjologia codzienności jako niebanalności, red. Z. Rykiel, J. Kinal, Rzeszów 2016.

Wawrzonek A., Młodzi dorośli na rynku pracy, „Studia Edukacyjne” 2014, nr 33. 
Wrzesień W., Czy pokoleniowość nam się nie przydarzy? Kilka uwag o współczesnej polskiej młodzie$\dot{z} y$, „Nauka” 3, 2007.

Xie C., Bagozzi R., Troye S., Trying to prosume: toward a theory of consumers as co-creatorsof value, „Journal of the Academy of Marketing Science” 2008, nr 36 (1).

\section{The young generation in terms of work, consumption and success}

\section{Summary}

The subject matter of the young generation in the social context has been repeatedly examined and many studies have been prepared on this topic, for example the works of K. Wyka and earlier $\mathrm{K}$. Manheim. Increasingly, the issue of the younger generation is discussed in the area of issues related to consumption and work. The article is of a theoretical and empirical nature; it is an attempt to portray the young generation in its two most important roles on the market - the consumer and the entrepreneur. It is an introductory element to the problems of consumer behaviors and entrepreneurial behaviors of the young generation. The publication draws attention to the expectations of the young generation about the applicable law and the economy. The first part of the article is characterized by sociological considerations and serves to determine the meaning of the young generation in consumer society, in particular, to outline the framework of youth, which in literature is sometimes defined not only by age categories. It is also an interdisciplinary review of theories, both those created in the past and those quite contemporary. In the second part, it refers to the results of qualitative research relating to the opinions and expectations of the young generation about consumption, work and success. 